\title{
Pengaruh Dosis Kompos Jerami Dan Pemangkasan terhadap Pertumbuhan dan Hasil Tanaman Mentimun (cucumis sativus $\mathbf{L}$.)
}

\author{
Effect of Straw Compost Dosage And Pruning on Growth and Cucumber Plant Results \\ (cucumis sativus L.) \\ Ahmad Amsar ${ }^{1}$, Halimursyadah ${ }^{1}$, Marai Rahmawati ${ }^{1}$ \\ ${ }^{1}$ Program Studi Agroteknologi, Fakultas Pertanian, Universitas Syiah Kuala
}

\begin{abstract}
Abstrak. Penelitian ini bertujuan untuk mengetahui dosis kompos jerami dan pemangkasan terhadap pertumbuhan dan hasil tanaman mentimun sehingga dapat menghasilkan pupuk yang ekonomis dan berproduksi tinggi untuk penanaman mentimun serta interaksi kedua faktor tersebut. Penelitian ini menggunakan Rancangan Acak Kelompok (RAK) pola faktorial $4 \times 3$ dengan 3 ulangan yang terdiri dari 2 faktor. Pengamatan yang diteliti yaitu panjang tanaman, umur berbunga, jumlah bunga betina, diameter buah, jumlah buah pertanaman, panjang buah, berat buah pertanaman, berat per buah dan potensi hasil. Hasil penelitian ini menunjukkan bahwa dosis kompos jerami berpengaruh sangat nyata terhadap diameter buah dan berpengaruh nyata terhadap berat per buah mentimun. Dosis terbaik pada hasil tanaman mentimun dijumpai pada perlakuan dosis kompos jerami 30 dan 20 ton/ha. Pada faktor pemangkasan berpengaruh sangat nyata terhadap panjang tanaman 21 HSPT dan 28 HSPT serta berpengaruh nyata terhadap jumlah bunga betina, panjang buah, berat buah per tanaman, berat per buah dan potensi hasil. pemangkasan terbaik pada pertumbuhan dan hasil tanaman mentimun dijumpai pada perlakuan tanpa pemangkasan dan pemangkasan tunas pada ruas 6-10.
\end{abstract}

Kata kunci : Mentimun, kompos jerami, pemangkasan, pertumbuhan, hasil.

\begin{abstract}
This study aims to determine the dosage of straw compost and pruning to the growth and yield of cucumber plants so as to produce fertilizer that is economical and high production for cucumber planting as well as interaction of these two factors. This study used Randomized Block Design (RAK) 4 x 3 factorial pattern with 3 replications consisting of 2 factors. Observations observed were plant length, flowering age, number of female flowers, fruit diameter, number of fruit crops, fruit length, fruit crop weight, weight per fruit and yield potential. The results of this study indicate that the dosage of straw compost has a very significant effect on the fruit diameter and has a significant effect on the weight per cucumber fruit. The best doses on cucumber yields were found in the treatment of straw compost doses of 30 and 20 tons / ha. In the pruning factor very significant effect on the length of plants 21 HSPT and 28 HSPT and significantly affect the number of female flowers, fruit length, fruit weight per plant, weight per fruit and yield potential. the best pruning on growth and yield of cucumber crops was found in the treatment without pruning and pruning of shoots in the 6-10 segments.
\end{abstract}

Keywords : cucumber, straw compost, pruning, growth, yield.

\section{PENDAHULUAN}

Mentimun (Cucumis sativus L.) merupakan tanaman sayuran yang termasuk dalam Famili Cucurbitaceae yang popular di seluruh dunia. Tanaman mentimun berasal dari Asia Utara, tetapi sebagian lagi menduga berasal dari Asia Selatan. Para ahli tanaman memastikan daerah asal tanaman mentimun adalah India, tepatnya di lereng gunung Himalaya (Purnomo et al., 2013). Mentimun dapat dimanfaat sebagai lalapan segar, bahan obat untuk mengobati beberapa penyakit dan bahan kosmetik untuk kecantikan (Amin, 2015).

Sejalan dengan meningkatnya jumlah penduduk Indonesia yang semakin meningkat dengan laju pertumbuhan 1,38 per tahun, namun tidak diimbangi dengan produksi bahan hortikultura terutama jenis sayur-sayuran (Badan Perencanaan Pembangunan Nasional, 2015). 
Hal ini menyebabkan permintaan mentimun terus bertambah baik di dalam negeri maupun luar negeri yang cukup besar, melihat dari potensi tersebut maka bisnis mentimun mempunyai prospek yang cukup cerah untuk dikembangkan (Surung dan Gusasi, 2007).

Produksi mentimun dapat ditingkatkan dengan melakukan perbaikan dalam teknik budidaya. Salah satu teknik budidaya yang intensif untuk meningkatkan hasil panen mentimun adalah pemupukan dan pemangkasan. Pemupukan adalah penambahan unsur hara yang dibutukan tanaman sesuai dengan dosis yang dianjurkan, salah satu pupuk yang digunakan yaitu kompos. Proses pengomposan (dekomposisi) merupakan metode utama yang digunakan untuk mendapatkan pupuk organik yang berkualitas tinggi dari bahan-bahan limbah organik, sehingga dengan pupuk organik ini diharapkan selain bernilai ekonomi, juga bersifat ramah lingkungan (Hermawati, 2007). Salah satu kompos yang baik untuk penanaman mentimun ialah kompos jerami, sebab jerami padi merupakan salah satu bahan yang mudah diolah menjadi pupuk organik dan bahan jerami padi mudah didapat terutama pada saat musim panen padi tiba. Selain itu, penggunaan kompos jerami padi dapat meminimalkan dan memperbaiki kualitas tanah yang menurun akibat dari penggunaan pupuk anorganik.

Selain dengan penambahan kompos, peningkatan produksi mentimun dapat dilakukan dengan pemangkasan. Pemangkasan ditujukan untuk mengendalikan pertumbuhan vegetatif suatu tanaman sehingga dapat merangsang pertumbuhan bagian-bagian tertentu pada suatu tanaman dan dapat mempercepat pertumbuhan generatif dari tanaman (Saprudin, 2013). Pemangkasan adalah tindakan pembuangan bagian-bagian tanaman, seperti cabang/ranting dengan mendapatkan bentuk tertentu sehingga dicapai tingkat efisiensi yang tinggi didalam pemanfaatan cahaya matahari, mempermudah pengendalian hama/penyakit, serta mempermudah pemanenan. Untuk meningkatkan hasil mentimun pada lahan terbatas diperlukan suatu cara agar petani dapat memproduksi mentimun dengan jumlah yang banyak. Salah satunya dengan pemangkasan cabang. Pemangkasan cabang bermanfaat mengurangi persaingan distribusi hasil fotosintesis antar daun dan buah (Zulkarnain, 2010).

Pertumbuhan daun yang berlebihan sebaiknya dipangkas, sebab peredaran udara di sekitar kanopi akan lebih baik, keadaan ini akan mengurangi kelembaban iklim mikro di sekitar tanaman dan seterusnya akan mengurangi serangan penyakit (Sutapradja, 2008). Menurut penelitian Soeb (2000) bahwa pemangkasan pada ruas satu sampai lima cabang dan bakal buah dibuang, lalu dipangkas pada ruas ke-6 sampai ke-12 ditinggalkan tiga daun dapat meningkatkan produksi tanaman mentimun. Pemangkasan mentimun membuat pengurangan daun-daun yang tidak bermafaat sehingga penyebaran nutrisi dapat optimal dan pertumbuhan buah lebih optimal. Susanto dan Pribadi (2004), menambahkan bahwa, pertumbuhan dan produksi tanaman mentimun dapat lebih baik dengan melakukan pemangkasan ujung cabang atau titik tumbuh cabang tanaman. Selain itu dengan tanaman, pemeliharaan dan pemanenan tanaman menjadi lebih mudah. 


\section{METODE PENELITIAN}

Penelitian ini dilaksanakan di Laboratorium Laboratorium Hortikultura Fakultas Pertanian Universitas Syiah Kuala, Darussalam Banda Aceh. Penelitian berlangsung pada bulan Agustus 2017 sampai dengan Oktober 2017.

\section{MATERI DAN METODE}

Benih mentimun Varietas F1 Hercules, kotoran sapi $500 \mathrm{~kg}$, sekam padi $100 \mathrm{~kg}$, jerami $500 \mathrm{~kg}$, EM4 3 botol $(1 \mathrm{~L})$ dan gula aren $2 \mathrm{~kg}$, Pupuk Urea $(100 \mathrm{~kg} / \mathrm{ha}$ dibutuhkan sebanyak $20 \mathrm{~g})$, SP-36 (150 kg/ha dibutuhkan sebanyak $30 \mathrm{~g}), \mathrm{KCl}(100 \mathrm{~kg} / \mathrm{ha}$ dibutuhkan sebanyak $20 \mathrm{~g}$ ), cangkul, garu, tali rafia, gunting, meteran, hand sprayer, gembor, timbangan duduk, timbangan analitik, jangka sorong, pengaris, alat tulis, kamera, bambu (ajir) dan triplek.

\section{Metode Penelitian}

\section{Pembuatan Kompos}

Teknik pembuatan kompos jerami padi, pada lapisan pertama masukkan sekam padi sebanyak 2 karung volume $10 \mathrm{~kg}$, pada lapisan kedua masukkan kotoran sapi sebanyak 10 ember (volume $10 \mathrm{~kg}$ ), pada lapisan ketiga masukkan jerami sebanyak 4 karung ukuran volume $10 \mathrm{~kg}$ dan kemudian disiram dengan EM4 sebanyak $300 \mathrm{ml}$ yang sebelumnya telah dicampurkan dengan $5 \mathrm{~L}$ air dan gula merah yang telah diencerkan, ulangi seterusnya sampai lapisan ke lima, tutup dengan terpal. Kompos jerami padi diaduk setiap minggu dan disiram dengan air hingga lembab. Proses pengomposan dilakukan 3 bulan. Ciri-ciri kompos yang sudah siap digunakan adalah berwarna coklat, bertekstur remah, berkonsistensi gembur, tidak panas dan tidak berbau menyengat.

\section{Pelaksanaan Penelitian}

Benih mentimun disemai dengan metode kertas digulung didirikan dalam plastik (UKDdp) selama 48 jam pada suhu kamar. Setelah berkecambah, benih ditanam dalam polybag persemaian dengan media campuran tanah dan pupuk kandang dengan perbandingan volume 2:1. Setiap polybag persemaian ditanam satu benih yg telah berkecambah. Persemaian diletakkan ditempat yang teduh dan dilakukan penyiraman pagi dan sore dengan menggunakan hand sprayer. Setelah bibit berumur 14 hari dipindahkan ke lapangan penanaman setelah ditandai tumbuhnya 4 helai daun. Plot-plot Percobaan dibuat dengan ukuran $2 \mathrm{~m} \times 1 \mathrm{~m}$ dengan tinggi $30 \mathrm{~cm}$ sebanyak 36 plot dengan jarak tanam tanaman mentimun ukuran $40 \mathrm{~cm} \times 40 \mathrm{~cm}$. Jarak antar plot $30 \mathrm{~cm}$ dan jarak antara kelompok $50 \mathrm{~cm}$.

Pemberian kompos dilakukan pada saat 7 hari sebelum tanam. Plot-plot percobaan diberikan pupuk kompos sesuai dengan jenis dan dosis yaitu $\mathrm{K}_{0}(0$ ton $/ \mathrm{ha})=0 \mathrm{~kg} / \mathrm{plot}, \mathrm{K}_{1}(10$ ton $/ \mathrm{ha})=2 \mathrm{~kg} / \mathrm{plot}, \mathrm{K}_{2}(20 \mathrm{ton} / \mathrm{ha})=4 \mathrm{~kg} / \mathrm{plot}, \mathrm{K}_{3}(30$ ton $/ \mathrm{ha})=6 \mathrm{~kg} / \mathrm{plot}$ dengan cara mencampur secara merata. Pemberian pupuk dasar dilakukan dua kali pemberian, pertama pada saat penanaman mentimun dengan $1 / 2$ dosis anjuran pupuk Urea $100 \mathrm{~kg} / \mathrm{ha}(50 \mathrm{~kg} / \mathrm{ha})=$ $20 \mathrm{~g}(10 \mathrm{~g} / \mathrm{plot})$, pupuk SP-36 $150 \mathrm{~kg} / \mathrm{ha}(75 \mathrm{~kg} / \mathrm{ha})=30 \mathrm{~g}(15 \mathrm{~g} / \mathrm{plot})$, pupuk $\mathrm{KCl} 100 \mathrm{~kg} / \mathrm{ha}$ $(50 \mathrm{~kg} / \mathrm{ha})=20 \mathrm{~g}(10 \mathrm{~g} / \mathrm{plot}) \mathrm{dan} 1 / 2$ dosis lagi $($ Urea $=10 \mathrm{~g} / \mathrm{plot}, \mathrm{SP}-36=15 \mathrm{~g} / \mathrm{plot}, \mathrm{KCl}=10$ 
g/plot) diberikan pada saat tanaman berumur 20 HSPT (Hari Setelah Pindah Tanam). Pemupukan dilakukan dengan cara larikan diantara barisan tanaman.

Pada saat pemindahan bibit sebaiknya dilakukan dengan hati-hati untuk menghindari kerusakan pada bibit. Bibit dipindahkan ke lapangan dengan cara membuat lubang tanam. Bibit yang dipindahkan terlebih dahulu diseleksi yang pertumbuhannya normal, dengan kriteria batang tumbuh lurus dan tegak, tidak cacat, berwarna hijau dan tidak terkena hama penyakit. Bibit ditanam tepat di bagian tengah lubang tanam.

\section{Pemangkasan Tanaman}

Pemangkasan dilakukan pada umur 19 HSPT. Alat yang digunakan untuk memangkas yaitu gunting yang terlebih dahulu direndam dalam larutan alkohol selama beberapa menit untuk mematikan mikroorganisme yang mungkin melekat pada alat tersebut. Pemangkasan tunas ruas pertama sampai tunas kelima yang tumbuh semuanya dipangkas, pemangkasan dilakukan segera setelah tunas muncul, atau paling lambat setelah daun sudah sepanjang 10$15 \mathrm{~cm}$. Pada tunas ruas keenam sampai tunas ruas kesepuluh pemangkasan tidak dilakukan secara keseluruhan tetapi, dengan menyisakan 3 helai daun dan 1 bakal buah. Pemangkasan dilakukan pada titik tumbuh tunas.

\section{Pemeliharaan Tanaman}

Kegiatan pemiliharaan meliputi: penyiraman dilakukan 2 kali dalam sehari dengan menggunakan gembor pada pagi hari dan sore hari, penyulaman dilakukan jika ada tanaman yang tidak tumbuh atau mengganti tanaman yang pertumbuhannya kurang baik dengan tanaman yang ada ditempat pembibitan dan dilakukan pada saat tanaman berumur 7 HSPT, pemasangan ajir dan lanjaran dilakukan pada 5 HSPT agar tidak menganggu sistem perakaran tanaman. Lanjaran yang digunakan yaitu tali yang dipasang membentang, setiap baris tanaman terdiri dari 2 buah lanjaran dengan posisi tegak dan ujung atasnya diikat, pengendalian virus gemini dengan cara mencabut tanaman yg telah terserang virus agar tidak menular ke tanaman lain. Pengendalian dilakukan pada umur 25-27 HSPT, penyiangan dan pembumbunan dilakukan apabila gulma sudah mulai tumbuh dengan cara dicabut dengan tangan sekaligus membumbun tanaman, dan pemanenan dilakukan pada tanaman berumur 33 HSPT. Kriteria panen buah mentimun adalah buah berukuran cukup besar, panjang $\pm 18-20$ $\mathrm{cm}$, kulit berwarna hijau keputihan serta hilangnya duri-duri yang ada pada kulit buah. Pemanenan dilakukan dengan interval waktu 3 hari sekali. Panen dilakukan 5 kali dengan memotong tangkai buah menggunakan pisau atau gunting.

\section{Analisis Statistik}

Penelitian ini menggunakan Rancangan Acak Kelompok (RAK) Pola faktorial 3x4 dengan dua faktor yang diteliti. Faktor pertama dosis kompos jerami (K) yang terdiri dari 4 taraf yaitu : $K_{0}$ (0 ton/ha), $K_{1}\left(10\right.$ ton/ha), $K_{2}$ (20 ton/ha) dan $K_{3}$ (30 ton/ha). Faktor kedua pemangkasan $(\mathrm{P})$ terdiri dari 3 taraf yaitu : $\mathrm{P}_{0}$ (Tanpa pemangkasan), $\mathrm{P}_{1}$ (Pemangkasan tunas pada ruas 1-5) dan $\mathrm{P}_{2}$ (Pemangkasan tunas pada ruas 6-10). Terdapat 12 jumlah kombinasi perlakuan, masing-masing kombinasi diulang sebanyak 3 kali, sehingga didapat 36 satuan percobaan. 


\section{HASIL DAN PEMBAHASAN}

\section{Pengaruh Dosis Kompos Jerami Terhadap Pertumbuhan dan Hasil Tanaman Mentimun}

Hasil Uji F pada analisis ragam menunjukkan bahwa dosis kompos jerami berpengaruh nyata terhadap berat per buah dan berpengaruh sangat nyata terhadap diameter buah per tanaman, namun berpengaruh tidak nyata terhadap tinggi tanaman mentimun umur 7, 14, 21 dan 28 HSPT, umur berbunga, jumlah buah per tanaman, panjang buah pertanaman, berat buah per tanaman dan potensi hasil. Rata-rata pertumbuhan dan hasil tanaman mentimun terhadap perlakuan dosis kompos jerami dapat dilihat pada Tabel 1.

Tabel 1. Rata-rata pertumbuhan dan hasil tanaman mentimun pada perlakuan dosis kompos jerami.

\begin{tabular}{|c|c|c|c|c|c|c|}
\hline \multicolumn{2}{|c|}{ Parameter yang diamati } & \multicolumn{4}{|c|}{ Dosis kompos Jerami (ton/ha) } & \multirow{2}{*}{$\mathrm{BNJ}_{0,05}$} \\
\hline & & $0\left(\mathrm{~K}_{0}\right)$ & $10\left(\mathrm{~K}_{1}\right)$ & $20\left(\mathrm{~K}_{2}\right)$ & $30\left(\mathrm{~K}_{3}\right)$ & \\
\hline \multirow{4}{*}{$\begin{array}{l}\text { Panjang tanaman } \\
(\mathrm{cm})\end{array}$} & 7 HSPT & 23,59 & 22,39 & 22,48 & 23,71 & - \\
\hline & 14 HSPT & 44,13 & 42,07 & 43,11 & 44,89 & - \\
\hline & $21 \mathrm{HSPT}$ & 95,64 & 91,27 & 92,09 & 93,91 & - \\
\hline & $28 \mathrm{HSPT}$ & 142,06 & 144,23 & 145,76 & 146,92 & - \\
\hline \multicolumn{2}{|c|}{ Umur berbunga (hspt) } & 18,87 & 19,18 & 18,80 & 19,09 & - \\
\hline \multicolumn{2}{|c|}{ Jumlah bunga betina (kuntum) } & 13,67 & 12,84 & 13,62 & 13,87 & - \\
\hline \multicolumn{2}{|c|}{ Diameter buah (mm) } & $47,53 \mathrm{a}$ & $47,65 \mathrm{a}$ & $49,10 \mathrm{ab}$ & $49,59 \mathrm{~b}$ & 1,41 \\
\hline \multicolumn{2}{|c|}{$\begin{array}{l}\text { Jumlah buah per tanaman } \\
\text { (buah) }\end{array}$} & 5,71 & 5,56 & 5,53 & 5,69 & 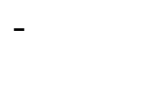 \\
\hline \multicolumn{2}{|c|}{ Panjang buah $(\mathrm{cm})$} & 19,79 & 20,34 & 21,02 & 21,10 & - \\
\hline \multicolumn{2}{|c|}{ Berat buah per tanaman $(\mathrm{kg})$} & 1,64 & 1,73 & 1,74 & 1,77 & - \\
\hline \multicolumn{2}{|l|}{ Berat per buah (g) } & $288,19 \mathrm{a}$ & $310,38 \mathrm{ab}$ & $315,67 \mathrm{~b}$ & $310,95 \mathrm{ab}$ & 23,18 \\
\hline \multicolumn{2}{|c|}{ Potensi hasil (ton/ha) } & 8,73 & 9,17 & 9,25 & 9,39 & - \\
\hline
\end{tabular}

Keterangan : Angka yang diikuti oleh huruf yang sama pada baris yang sama berbeda tidak nyata pada taraf peluang $5 \%\left(\mathrm{BNJ}_{0,05}\right)$

Hasil penelitian menunjukkan bahwa dosis kompos jerami berpengaruh sangat nyata terhadap diameter buah dan berpengaruh nyata terhadap berat per buah mentimun. sesuai hasil penelitian tersebut, menunjukkan bahwa dosis terbaik pada hasil tanaman mentimun dijumpai pada perlakuan dosis kompos jerami $\mathrm{K}_{3}$ (30 ton/ha) yaitu pada parameter diameter buah sebesar 49,59 $\mathrm{mm}$ dan perlakuan dosis kompos jerami $\mathrm{K}_{2}$ (20 ton/ha) yaitu pada parameter berat per buah sebesar 315,67 g. Hal ini diduga bahwa dosis kompos jerami mampu memperbaiki sifat fisika, kimia dan biologi tanah sehingga memberikan pengaruh terhadap diameter buah dan berat per buah.

Hal ini menunjukkan bahwa semakin tinggi dosis kompos jerami yang diberikan, semakin meningkat hasil tanaman mentimun. Kompos jerami mampu memperbaiki sifat biologi tanah sehingga tercipta lingkungan yang lebih baik bagi perakaran tanaman. Bahan organik jerami dapat mensuplai unsur hara terutama N, P dan K. Semua unsur-unsur tersebut memegang peran yang sangat penting dalam metabolisme tanaman. Hal ini sesuai dengan pernyataan Sutanto (2002) bahwa kompos jerami padi berpotensi memperbaiki tata udara dan 
air tanah sehingga perakaran tanaman akan berkembang dengan baik dan akar dapat menyerap unsur hara yang lebih banyak, terutama unsur hara $\mathrm{N}$ yang akan meningkatkan pembentukan klorofil, sehingga aktivitas fotosintesis lebih meningkat dan dapat meningkatkan ekspansi luas daun, karena mengandung N, P, S, K, Si dan C organik.

Dari hasil uji laboratorium penelitian tanah dan tanaman (Lampiran 30), kompos jerami yang digunakan dalam penelitian ini mengandung Nitrogen $1,19 \%, \mathrm{P}_{2} \mathrm{O}_{5} 0,61 \%, \mathrm{~K}_{2} \mathrm{O}$ 1,18\%, $\mathrm{CaO} 0,14 \%, \mathrm{MgO} 0,31 \%, \mathrm{C} / \mathrm{N} 8,56 \%$ dan $\mathrm{C}$ organik 10,19\%. Berdasarkan hasil analisis tersebut, bahwa kompos jerami mampu mensuplai unsur hara dalam tanah, walaupun dalam jumlah sedikit. Semakin tinggi dosis kompos jerami yang diberikan maka semakin banyak unsur hara yang tersedia.

Hasil penelitian Pangaribuan dan Pujisiswanto (2008) menunjukkan bahwa aplikasi kompos jerami berpengaruh positif terhadap pertumbuhan dan produksi tomat. Hal ini berkaitan dengan kemampuan bahan organik jerami padi dalam memperbaiki sifat biologi tanah sehingga tercipta lingkungan yang lebih baik bagi perakaran tanaman, sehingga bahan organik jerami padi dapat menyediakan unsur hara terutama N, P dan K. Semua unsur-unsur tersebut memegang peran yang sangat penting dalam metabolisme tanaman. Penelitian Anom (2008) menyatakan bahwa pemberian Tricho-Kompos jerami padi 10 ton/ha sampai 25 ton/ha, menunjukkan bahwa kandungan unsur hara tersedia lebih tinggi bagi tanaman sawi sehingga dapat meningkatkan berat segar tanaman sawi.

Menurut Gusmailina et al. (2003) bahwa pupuk organik seperti kompos jerami padi dapat memperbaiki struktur dan tekstur tanah. Penggunaan kompos jerami padi dapat mengurangi pemadatan tanah karena semakin banyak pori-pori menyebabkan akar tanaman semakin tumbuh lebih baik sehingga tingkat pengambilan hara semakin tinggi sesuai kebutuhan tanaman. Sementara menurut Syukur dan Indah (2006) semakin banyak bahan organik yang ditambahkan kedalam tanah semakin banyak pula $\mathrm{C}$ organik yang dilepaskan kedalam tanah. Akibat dari pemberian kompos jerami padi pada tanah menyebabkan kondisi tanah menjadi lebih baik terutama ketersediaan hara seperti $\mathrm{N}, \mathrm{P}, \mathrm{K}$, dan unsur-unsur hara mikro bagi tanaman.

Hasil diameter buah tanaman mentimun terbaik dijumpai pada perlakuan dosis kompos jerami 30 ton/ha. Hal ini dikarenakan tersedianya unsur hara dalam jumlah yang cukup menyebabkan kegiatan metabolisme dari tanaman akan meningkat sehingga terjadi pembesaran pada diameter buah. Diameter buah dipengaruhi oleh unsur hara yang tersedia dari dalam tanah dan penambahan unsur hara dari pemberian pupuk kompos jerami padi. Menurut penelitian Elkas et al., (2017) menyatakan bahwa unsur P dan K yang tedapat pada kompos jerami sangat berperan dalam meningkatkan diameter buah tanaman, khususnya sebagai jaringan yang menghubungkan antara akar dan buah. Tersedianya unsur hara $\mathrm{P}$ dan $\mathrm{K}$ mengakibatkan pembentukan karbohidrat akan berjalan dengan baik dan translokasi pati ke buah akan semakin lancar, sehingga akan terbentuk buah yang baik.

Kompos jerami padi dapat meningkatkan hasil tanaman karena kompos jerami menjadi salah satu sumber bahan organik bagi tanah. Hal ini sesuai dengan pernyataan Harsanti et al., (2012) bahwa pasokan hara dari bahan organik seperti kompos jerami padi mampu memperbaiki struktur tanah sehingga mendukung pertumbuhan tanaman untuk meningkatkan produktivitas tanaman. Penelitian Tamtomo et al., (2015) menunjukkan bahwa 
Pemberian kompos jerami 20 ton/ha mampu menyediakan unsur hara untuk pembentukan dan pembesaran umbi sehingga memberikan respon positif terhadap berat umbi tanaman ubi jalar. Sukasih (2016) menambahkan, bahwa dosis kompos jerami padi $3 \mathrm{~kg}$ per $\mathrm{m}^{2}$ atau $30 \mathrm{ton} / \mathrm{ha}$ dapat memberikan hasil terbaik berat segar per tanaman kailan.

\section{Pengaruh Pemangkasan Terhadap Pertumbuhan dan Hasil Tanaman Mentimun}

Hasil Uji F pada analisis ragam menunjukkan bahwa pemangkasan berpengaruh sangat nyata terhadap panjang tanaman 21 HSPT dan 28 HSPT, namun berpengaruh nyata terhadap jumlah bunga betina, panjang buah, berat buah per tanaman, berat per buah dan potensi hasil serta berpengaruh tidak nyata terhadap panjang tanaman mentimun umur 7 dan14, umur berbunga, diameter buah dan jumlah buah pertanaman. Rata-rata pertumbuhan dan hasil tanaman mentimun terhadap perlakuan pemangkasan dapat dilihat pada Tabel 2.

Tabel 2. Rata-rata pertumbuhan dan hasil tanaman mentimun pada perlakuan pemangkasan.

\begin{tabular}{|c|c|c|c|c|c|}
\hline \multicolumn{2}{|c|}{ Parameter yang diamati } & \multicolumn{3}{|c|}{ Pemangkasan } & \multirow{2}{*}{$\begin{array}{c}\mathrm{BNJ}_{0,0} \\
5 \\
\end{array}$} \\
\hline & & $\begin{array}{c}\text { Tanpa } \\
\text { pemangkasan } \\
\left(\mathrm{P}_{0}\right)\end{array}$ & $\begin{array}{c}\text { Pemangkasan } \\
\text { tunas pada } \\
\text { ruas } 1-5\left(\mathrm{P}_{1}\right)\end{array}$ & $\begin{array}{c}\text { Pemangkasan } \\
\text { tunas pada } \\
\text { ruas 6-10 }\left(\mathrm{P}_{2}\right)\end{array}$ & \\
\hline \multirow{4}{*}{$\begin{array}{l}\text { Panjang tanaman } \\
(\mathrm{cm})\end{array}$} & 7 HSPT & 23,05 & 21,63 & 24,44 & - \\
\hline & 14 HSPT & 45,70 & 38,48 & 46,47 & - \\
\hline & $21 \mathrm{HSPT}$ & $97,87 \mathrm{~b}$ & $82,70 \mathrm{a}$ & $99,12 b$ & 12,33 \\
\hline & 28 HSPT & $148,01 \mathrm{~b}$ & $135,89 \mathrm{a}$ & $150,33 \mathrm{~b}$ & 12,22 \\
\hline \multicolumn{2}{|c|}{ Umur berbunga (hspt) } & 19,20 & 19,05 & 18,70 & - \\
\hline \multicolumn{2}{|c|}{ Jumlah bunga betina (kuntum) } & $13,97 \mathrm{~b}$ & $12,97 \mathrm{a}$ & $13,57 \mathrm{ab}$ & 0,89 \\
\hline \multicolumn{2}{|c|}{ Diameter buah (mm) } & 48,68 & 47,86 & 48,87 & - \\
\hline \multicolumn{2}{|c|}{$\begin{array}{l}\text { Jumlah buah per tanaman } \\
\text { (buah) }\end{array}$} & 5,78 & 5,48 & 5,65 & - \\
\hline \multicolumn{2}{|l|}{ Panjang buah (cm) } & $21,29 \mathrm{~b}$ & 19,96 a & $20,44 \mathrm{ab}$ & 1,41 \\
\hline \multicolumn{2}{|c|}{ Berat buah per tanaman $(\mathrm{kg})$} & $1,70 \mathrm{ab}$ & $1,68 \mathrm{a}$ & $1,79 \mathrm{~b}$ & 0,12 \\
\hline \multicolumn{2}{|l|}{ Berat per buah (g) } & $302,64 \mathrm{ab}$ & $294,88 \mathrm{a}$ & $321,37 \mathrm{~b}$ & 24,18 \\
\hline \multicolumn{2}{|c|}{ Potensi hasil (ton/ha) } & $9,01 \mathrm{ab}$ & $8,91 \mathrm{a}$ & $9,49 \mathrm{~b}$ & 0,65 \\
\hline
\end{tabular}

Keterangan : Angka yang diikuti oleh huruf yang sama pada baris yang sama berbeda tidak nyata pada taraf peluang $5 \%\left(\mathrm{BNJ}_{0,05}\right)$

Hasil penelitian menunjukan bahwa pemangkasan berpengaruh sangat nyata terhadap panjang tanaman 21 HSPT dan 28 HSPT serta berpengaruh nyata terhadap jumlah bunga betina, panjang buah, berat buah per tanaman, berat per buah dan potensi hasil. Sesuai dengan penelitian tersebut, bahwa pemangkasan terbaik pada pertumbuhan dan hasil tanaman mentimun dijumpai pada perlakuan tanpa pemangkasan $\left(\mathrm{P}_{0}\right)$ yaitu jumlah bunga $(13,97)$ dan panjang buah mentimun $(21,29 \mathrm{~cm})$, sedangkan pada parameter panjang tanaman $21(99,12$ $\mathrm{cm})$ dan 28 HSPT $(150,33 \mathrm{~cm})$, berat buah pertanaman $(1,79 \mathrm{~kg})$, berat per buah $(321,37 \mathrm{~g})$ dan potensi hasil $\left(9,49\right.$ ton/ha) yaitu pada perlakuan pemangkasan tunas pada ruas $6-10\left(\mathrm{P}_{2}\right)$. 
Hal ini menunjukkan bahwa pemangkasan yang dilakukan dapat meningkatkan pertumbuhan dan hasil tanaman mentimun. Hal ini diduga berkaitan dengan suplai air, nutrisi dan fotosintat yang lebih tinggi sehingga mendorong proses-proses pembelahan sel, pembesaran dan pemanjangan sel pada batang tanaman menjadi lebih seimbang untuk kebutuhan pertumbuhan vegetatif dan generatif.

Penelitian Idris (2004) menunjukkan bahwa pemangksasan pada ruas satu sampai lima seluruh cabang dan bakal buah dibuang lalu dipangkas pada ruas keenam sampai dua belas ditinggalkan tiga daun dapat meningkatkan produksi tanaman mentimun. Pemangkasan mentimun membuat pengurangan daun yang tidak bermanfaat sehingga penyebaran nutrisi dapat optimal dan pertumbuhan buah pun menjadi lebih optimal. Menurut Suwito (1990) jika daun terlalu lebat, maka harus dilakukan pemangkasan, dengan cara memotong pada daun tanaman dan ditinggalkan 3-4 helai daun saja, dengan perlakuan pemangkasan maka tanaman akan cepat bercabang dan berbuah.

Menurut Zulkarnain (2010), pemangkasan merupakan tindakan pembuangan bagianbagian tanaman, sehingga memperoleh bentuk tertentu yang akan meningkatkan efisiensi di dalam pemanfaatan sinar matahari, mempermudah pengendalian hama dan penyakit, juga pemanenan. Berdasarkan penelitian Yulianto (2012) menyatakan bahwa pemangkasan pucuk pada ruas ke-15 meningkatkan jumlah buah yang dihasilkan. Meningkatnya jumlah cabang produktif tanaman akibat pemangkasan pucuk menyebabkan buah yang terbentuk dan jumlah daun lebih banyak dan produktif.

Pada fase generatif hampir seluruh hasil fotosintesis akan digunakan oleh bunga dan buah yang sedang berkembang. Sesuai dengan penelitian Zamzami et al., (2015) respon tanaman mentimun terhadap pemangkasan dengan menyisakan 12 ruas menghasilkan bobot buah lebih tinggi. Pemangkasan yang dilakukan pada saat yang tepat akan merangsang pertumbuhan tunas lateral menjadi tunas yang lebih produktif. Menurut Dewani (2000) apabila pemangkasan tidak dilakukan sedangkan faktor lingkungan mendukung, maka tanaman akan terus melakukan pertumbuhan vegetatif terus-menerus, sehingga pertumbuhan generatif bisa terhambat. Selain itu cahaya matahari yang masuk ke tanaman lebih banyak, sehingga akan merangsang pembentukan bunga.

Pemangkasan dapat mengurangi persaingan fotosintesis antar daun dan buah, sehingga dapat mengoptimalkan pembentukan buah. Mengurangi daun-daun yang tidak bermanfaat menyebabkan penyebaran nutrisi pada buah menjadi lebih optimal. Menurut Penelitian Gustianty (2016) menunjukkan bahwa pemangkasan sampai ruas ke-6 dan seterusnya ditinggalkan tiga daun menyebabkan terjadinya pembelahan, pembesaran, dan pengembangan sel sehingga mendorong produksi buah segar pada tanaman mentimun. Sesuai dengan penelitian Budiyanto et al., (2010) bahwa pemangkasan cabang umur 21 hari setelah tanam terjadinya pertumbuhan cabang, daun yang sangat lebat, sehingga apabila dilakukan pemangkasan cabang akan merangsang terbentuknya cabang-cabang baru yang produktif menghasilkan bunga dan buah. 


\section{Pengaruh Interaksi antara Dosis Kompos Jerami dan Pemangkasan terhadap Pertumbuhan dan Hasil Tanaman Mentimun}

Hasil uji $\mathrm{F}$ pada analisis ragam menunjukkan bahwa terdapat interaksi yang tidak nyata antara dosis kompos jerami dan pemangkasan terhadap semua parameter yang diamati yaitu panjang tanaman umur 7,14,21 dan 28 HSPT, umur berbunga, jumlah bunga betina, diameter buah, jumlah buah per tanaman, panjang buah, berat buah per tanaman, berat per buah dan potensi hasil.

Hasil penelitian menunjukkan bahwa terdapat interaksi yang tidak nyata antara dosis kompos jerami dengan pemangkasan terhadap semua parameter pertumbuhan dan hasil tanaman mentimun. Hal ini karena perbedaan pertumbuhan dan hasil tanaman mentimun akibat dosis kompos jerami pada taraf dosis yang berbeda tidak dipengaruhi oleh pemangkasan dan begitu juga dengan perbedaan perlakuan pemangkasan tidak dipengaruhi oleh perlakuan dosis kompos jerami.

\section{KESIMPULAN DAN SARAN}

Dosis terbaik pada hasil tanaman mentimun dijumpai pada kompos jerami 30 ton/ha yaitu pada parameter diameter buah dan perlakuan dosis kompos jerami 20 ton/ha yaitu pada parameter berat per buah. Pemangkasan terbaik pada pertumbuhan dan hasil tanaman mentimun dijumpai pada perlakuan pemangkasan tunas pada ruas 6-10 yaitu panjang tanaman 21 dan 28 HSPT, berat buah pertanaman, berat per buah dan potensi hasil. Terdapat interaksi yang tidak nyata antara kompos jerami dengan pemangkasan terhadap semua parameter yang diamati.

\section{DAFTAR PUSTAKA}

Amin, A. R. 2015. Mengenal budidaya mentimun melalui pemanfaatan media informasi. Jurnal Jupiter 14 (1) : 66-71.

Anom, E. 2008. Efek residu pemberian tricho-kompos jerami padi terhadap pertumbuhan dan produksi sawi hijau (Brassica juncea L). Jurnal Sagu 7 (2) : 7-12.

Badan Perencanaan Pembangunan Nasional. 2015. Proyeksi Penduduk Indonesia 2010-2035. Online. http://www. Datastatistik-Indonesia.com. Diakses tanggal : 2 April 2017.

Budiyanto., O. D. Hajoeningtijas dan B. Nugroho. 2010. Pengaruh saat pemangkasan cabang dan kadar paklobutrazol terhadap hasil mentimun (Cucumis sativus L.). Jurnal Agritech 12 (2) : 100-113.

Dewani, M. 2000. Pengaruh pemangkasan terhadap pertumbuhan dan hasil tanaman kacang hijau (Vigna rediata L.) Varietas Walet dan Wongsorejo. Jurnal Agrista 12 (1) : 18-23.

Elkas, B. D., T. Nurhidayah dan Nurbaiti. 2017. Pengaruh pemberian kompos jerami padi terhadap pertumbuhan bibit tanaman kakao (Theobroma cacao L.). Jom Faperta 4 (1) : $1-14$. 
Gusmailina., P. Gustan dan K. Sri. 2003. Pengembangan penggunaan arang untuk rehabilitasi lahan. Bulletin Penelitian dan Pengembangan Kehutanan 4 (1) : 21-30.

Gustianty, L. R. 2016. Respon pertumbuhan dan produksi tanaman mentimun (cucumis sativus L.) terhadap pupuk seprint dan pemangkasan. Jurnal Penelitian Pertanian BERNAS. 12 (2) : 55-64.

Harsanti, E. S., Indratin dan A. Wihardjaka. 2012. Multifungsi kompos jerami dalam sistem produksi padi berkelanjutan di Ekosistem Sawah Tadah Hujan. Jurnal Agroinovasi 24.

Hermawati, T. 2007. Pengaruh pemberian kompos sampah kota terhadap hasil tanaman mentimun (Cucumis sativus L.). Jurnal Agronomi 11 (1) : 23-26.

Idris, M . 2004. Respon tanaman mentimun (Cucumis Sativus L.) akibat pemangkasan dan pemberian pupuk ZA. Jurnal Penelitian Bidang Ilmu Pertanian 2 (1) : 17-24.

Pangaribuan, D dan H. Pujisiswanto. 2008. Pemanfaatan kompos jerami untuk meningkatkan produksi dan kualitas buah tomat. Prosiding Seminar Nasional Sains dan Teknologi. Jurusan Budidaya Pertanian, Universitas Lampung, Bandar Lampung.

Pribadi, E. M. 2001. Pengaruh pemangkasan cabang dan penjarangan bunga jantan terhadap pertumbuhan dan produksi ketimun dengan budidaya hidroponik. Skripsi. Jurusan Budidaya Pertanian, Fakultas Pertanian Institut Pertanian Bogor, Bogor.

Purnomo, R., M. Santoso dan S. Heddy. 2013. Pengaruh berbagai macam pupuk organik dan anorganik terhadap pertumbuhan dan hasil tanaman mentimun (Cucumis sativus L.). Jurnal Produksi Tanaman 1 (3) : 93-100.

Saprudin, 2013. Pengaruh umur tanaman pada saat pemangkasan terhadap pertumbuhan dan produksi ketimun (Cucumis sativus L.). Jurnal Juristek 1 (2) : 51-62.

Soeb, M. 2000, Pengaruh pemangkasan dan pemberian mulsa terhadap pertumbuhan dan produksi tanaman mentimun (Cucumis sativus L.). Skripsi. Fakultas Pertanian, Universitas Sumatera Utara, Medan.

Sukasih, N. S. 2016. Pengaruh kompos jerami padi terhadap pertumbuhan dan hasil tanaman kailan (Brassica alboglabra L.) pada tanah podsolik merah kuning. Jurnal Piper 12 (23) : 125-134.

Surung, M. Y dan A. Gusasi. 2007. Respon tanaman mentimun hibrida (Cucumis sativus L.) terhadap pemberian berbagai konsentrasi EM4. Jurnal Agrisistem. 3 (1) : 9-12.

Sutanto, R. 2002. Penerapan Pertanian Organik (Pemasyarakatan dan Pengembangannya). Kanisius, Yogyakarta. 
Sutapradja, H. 2008. Pengaruh Pemangkasan Pucuk terhadap Hasil dan Kualitas Benih Lima Kultivar Mentimun. Jurnal Hort 18 (1) : 16-20.

Suwinto, 1990. Memanfaatkan Lahan Bercocok Tanam Mentimun Hibrida. Kanisius, Yogyakarta.

Syukur, A dan N. M. Indah. 2006. Kajian pengaruh pemberian macam pupuk organik terhadap pertumbuhan dan hasil tanaman jahe di inceptisol, Karanganyar. Jurnal Ilmu Tanah dan Lingkungan 6 (2) : 124-131.

Tamtomo, F., S. Rahayu dan A. Suyanto. 2015. Pengaruh aplikasi kompos jerami dan abu sekam padi terhadap produksi kadar pati ubi jalar. Jurnal Agrosains. 12 (2) : 1-7.

Yulianto, D. 2012. Pengaruh pemangkasan pada budidaya mentimun (Cucumis Sativus L.). Makalah penelitian. Politeknik Negeri Lampung, Bandar Lampung.

Zamzami, K., M. Nawawi dan N. Aini. 2015. Pengaruh jumlah tanaman per polybag dan pemangkasan terhadap pertumbuhan dan hasil tanaman mentimun kyuri. Jurnal Produksi Tanaman 3 (2) : 113-119.

Zulkarnain, H. 2010. Dasar Dasar Hortikultura. Bumi Aksara, Jakarta. 